\title{
Polycyclic aromatic hydrocarbons and polychlorinated biphenyls in urban soils from Kathmandu, Nepal
}

\author{
B. Aichner *, B. Glaser, W. Zech \\ Institute of Soil Science and Soil Geography, University of Bayreuth, D-95440 Bayreuth, Germany \\ Received 20 March 2006; received in revised form 1 November 2006; accepted 2 November 2006 \\ Available online 21 February 2007
}

\begin{abstract}
Kathmandu, the capital of Nepal, faces increasing environmental problems such as heavy air pollution and lack of proper waste management. The aim of this study was to examine if the soils are also affected by pollution, with the focus on polycyclic aromatic hydrocarbons (PAHs) and polychlorinated biphenyls (PCBs). The sum of 20 PAHs in surface soils ranged between 184 and $10279 \mu \mathrm{g} \mathrm{kg}^{-1}$. The most abundant PAHs were perylene $(14.6 \%)$, benzo $(b+j+k)$ flouranthene $(10.7 \%)$, naphthalene $(10.7 \%)$ and phenanthrene $(9.8 \%)$, with perylene concentrations varying strongly. The significantly more positive $\delta^{13} \mathrm{C}$ values of perylene in samples with elevated concentrations indicate biological production, possibly by anaerobic degradation of perylene quinones. PAH ratios also indicate the influence of petrogenic PAH sources, especially at petrol stations and some street samples. The sum of 12 PCBs ranged from 356 to $44710 \mathrm{ng} \mathrm{kg}^{-1}$. The most abundant were congeners $52(19.4 \%), 101(14.3 \%), 118(13.4 \%)$ and $138(11.7 \%)$. The low PCB concentrations and pattern were interpreted as a diffuse background contamination being the main PCB source in the urban soils. Indications for recent contamination were found in river sediments from the inner city, as well as in industrial and street samples. Classified by land use, the samples taken from the gutter contained the highest PAH and PCB concentrations as a result of accumulation. The lowest values were found in surface soils from Swayambunath (a park) and a garden area. A gradual decrease in concentration with depth was present for both compound classes in the profiles sampled at Swayambunath. No trend was visible in the garden profiles as a result of soil disturbance of the soil by agricultural treatment. Enhanced microbial degradation and volatilization in the warm/humid monsoon climate is probably the main cause for low pollutant concentrations. Increased photodegradation and the short accumulation period might be other important factors. Concerning its state of soil pollution, Kathmandu fits rather well into a global distribution pattern of persistent organic pollutants, with high concentrations in temperate (higher latitude) regions and very low ones in the tropics (lower latitude regions) due to global distillation.
\end{abstract}

(C) 2006 Elsevier Ltd. All rights reserved.

\footnotetext{
* Corresponding author. Tel.: + 49331288 2194; fax: +49 331 2882137.

E-mail address: Bernhard.Aichner@awi.de (B. Aichner).
}

\section{Introduction}

Kathmandu, the capital of Nepal, faces increasing environmental problems caused by rapid and uncontrolled urbanization (HMNG-MoPE, 2000). 
A major factor of concern is heavy air pollution, which is caused by traffic and industrial exhaust (Shrestha and Malla, 1996; Sharma, 1997). This is enhanced by the location of the city in a basin-like valley, which acts as a trap for aerosols (Gautam et al., 2004). Like most developing countries, Nepal still lacks proper waste management and an environmental consciousness among the population, which results in uncontrolled disposal of hazardous waste, especially onto the river banks (Pokhrel and Viraraghavan, 2005). The aim of this study was to examine if the soils in the Kathmandu valley are also affected by environmental pollution, or if processes like biodegradation, volatilization or photodegradation predominate due to the warm/humid monsoon climate and the relatively high altitude.

Soils are an important sink in pollution cycling (Mackay et al., 1991; Marschner, 1998). However, they can also act as a contributor of persistent organic pollutants (POPs) to the atmosphere, especially of semi-volatile compounds in warm climates (Dalla Valle et al., 2005). Usually, urban soils show greater contamination than rural sites, due to the vicinity to point sources (Eusterbrock, 1999; Omar et al., 2002). Today, urban soils in temperate regions have been examined quite well with respect to their pollution status. More recently, research interest has shifted to tropical and subtropical regions. Some studies indicate a low state of pollution by POPs in these regions, possibly due to enhanced volatilization and microbial degradation (Wilcke et al., 1999a,b, 2003a). Iwata et al. (1994) found a positive correlation between organochlorine concentration ratios in sediment and water phases and sampling latitude, which suggested that persistent and semivolatile compounds discharged in the tropics tend to be redistributed on a global scale, especially at higher latitude (Wania and Mackay, 1996; Gouin et al., 2004), a phenomenon known as "global distillation".

Polycyclic aromatic hydrocarbons (PAHs) are a class of POPs produced by incomplete combustion of organic material (Bliefert, 1997). Their main source in the environment is of anthropogenic origin, namely combustion of fossil fuels such as petroleum and coal containing considerable amounts of PAHs (Wilcke, 2000; Bamforth and Singleton, 2005). There are also natural pyrogenic sources like vegetation fires or volcanic eruptions. Additionally, biological formation of perylene under anaerobic conditions has been reported (Venkatesan, 1988). PAHs are closely connected to aerosols or soot par- ticles produced by industrial or traffic exhaust (Mantis et al., 2005). Accordingly, they are of special interest in heavily polluted urban areas. As ubiquitous contaminants, they are particularly harmful as a result of their carcinogenic and mutagenic properties (Eisenbrandt and Metzler, 1994).

In contrast to PAHs, polychlorinated biphenyls (PCBs) are solely of industrial origin. Since the end of the 1920s they have been widely used in electrical equipment like capacitors and transformers, and as hydraulic fluids, flame retardants, plasticizers, heat exchangers, or additives in pesticides (Erickson, 2001). However, they are also persistent environmental pollutants that bioaccumulate in the food chain. In humans, certain congeners are teratogenic, immunogenic or carcinogenic and act as environmental estrogens (Eisenbrandt and Metzler, 1994). Therefore, their manufacture, use and importation have been phased out since the 1970s (Breivik et al., 2002). However, closed systems with long service life (e.g. transformers and hydraulic systems) containing PCBs are still partly in use. Inadequate scrapping and disposal can lead to further emissions (Bliefert, 1997).

\section{Material and methods}

\subsection{Sampling sites, sampling and standard analysis}

Kathmandu is situated in the Kathmandu Valley, which is inhabited by about 1.6 million people and contains Patan, which is separated from Kathmandu only by the Bagmati River, and some smaller villages (HMNG-MoPE, 2003). The valley is located within the Middle Mountain Zone, between $27^{\circ} 37^{\prime} 30^{\prime \prime} \mathrm{N}$ and $27^{\circ} 45^{\prime} 00^{\prime \prime} \mathrm{N}$, and $85^{\circ} 15^{\prime} 00^{\prime \prime} \mathrm{E}$ and $85^{\circ} 22^{\prime} 30^{\prime \prime} \mathrm{E}$ (Sapkota and Dhaubhadel, 2002), and has a basin-like shape with a diameter of $30 \mathrm{~km}$ $\mathrm{E}-\mathrm{W}$ and $25 \mathrm{~km} \mathrm{~N}-\mathrm{S}$. The surrounding mountains are between 2000 and $2800 \mathrm{~m}$ above sea level (a.s.1.) and the valley floor is on average $1350 \mathrm{~m}$ a.s.l. The soils, derived mainly from lacustrine and fluviatile sediments (HMND-MoPE, 2000) are classified as Fluvisols according to the World Reference Base (FAO, 1998). About $80 \%$ of the mean annual precipitation of $1400 \mathrm{~mm}$ falls between June and September. The mean annual temperature is about $18^{\circ} \mathrm{C}$ (HMNG-MFD, 2005).

Sampling of the 39 surface soil samples $(0-5 \mathrm{~cm})$ was conducted with a steel spatula between April 17th and 20th, 2004. The samples are categorized into nine land-use classes: street (ST), park (PA), 
industrial district (IN), river sediment (RI), residential area (RE), petrol station (PE), gutter (GU), garden area (GA) and a second park, called Swayambunath (SW), situated on a hill. Three profiles were sampled with an Edelman auger at 0-5, 510 and $10-15 \mathrm{~cm}$ depth in Swayambunath and 0-10, 10-20 and $20-30 \mathrm{~cm}$ depth at the garden site. Additionally, litter samples (L) were taken at Swayambunath. A detailed description of the land-use classes is given in Table 1. Fig. 1 shows the positions of the sampling sites. The samples were transported in closed aluminium containers to the laboratory where they were air-dried for $4 \mathrm{~d}$ before sieving $(<2 \mathrm{~mm})$. Organic carbon, total nitrogen, $\mathrm{pH}$, electric conductivity and texture were determined according to standard methods.

\section{2. $P A H$ and $P C B$ analysis}

Between 10 and $20 \mathrm{~g}$ of sample were filled in to cells for accelerated solvent extraction (ASE). The cells were filled with coarse Celite 545 coarse (FLUKA, Sigma-Aldrich, Steinheim, Germany). Prior to analysis, $100 \mu \mathrm{L}$ of a solution with eight deuteriated PAHs (NAPH-D8, ACE-D10, FLUD10, ANT-D10, PYR-D10, CHR-D12, PER-D12, BGHI-D12 at $4 \mu \mathrm{g} \mathrm{mL}^{-1}$ ) and $25 \mu \mathrm{L}$ of a solution with seven ${ }^{13} \mathrm{C}$-marked PCBs (PCB $28-{ }^{13} \mathrm{C}, \mathrm{PCB}$ $52-{ }^{13} \mathrm{C}$, PCB $101-{ }^{13} \mathrm{C}$, PCB $138-{ }^{13} \mathrm{C}$, PCB $153-{ }^{13} \mathrm{C}$, PCB $180-{ }^{13} \mathrm{C}$, PCB $209-{ }^{13} \mathrm{C}$ at $0.3 \mu \mathrm{g} \mathrm{mL}^{-1}$ ) were added to the soil as internal standards. Extraction was conducted with an Accelerated Solvent Extractor (Dionex ASE 200, Dionex Co., Sunnyvale, CA) using hexane:acetone $(2: 1)$ as solvent. Each sample was extracted in two cycles of $5 \mathrm{~min}$ at $1.4 \mathrm{MPa}$ and $120^{\circ} \mathrm{C}$. Extracts were evaporated to $1 \mathrm{~mL}$ and dried with $\mathrm{Na}_{2} \mathrm{SO}_{4}$. They were cleaned up using solid phase extraction with $2 \mathrm{~g} \mathrm{Al}_{2} \mathrm{O}_{3}$ (MP Biomedicals, Eschwege, Germany) in the upper part and $2 \mathrm{~g}$ silica gel (Merck, Darmstadt, Germany) in the lower part, both deactivated with $5 \%$ deonized $\mathrm{H}_{2} \mathrm{O}$. The column was eluted sequentially with $15 \mathrm{~mL}$ hexane, $5 \mathrm{~mL}$ hexane: $\mathrm{CH}_{2} \mathrm{Cl}_{2}(9: 1)$, and $20 \mathrm{~mL}$ hexane: $\mathrm{CH}_{2} \mathrm{Cl}_{2}$ (4:1). The PAHs were concentrated in toluene with a rotary evaporator at $35^{\circ} \mathrm{C}$ and $280 \mathrm{mbar}$ and spiked with $25 \mu \mathrm{L}$ FLA-D10 (20.04 $\mu \mathrm{g} \mathrm{mL}^{-1}$ ) for quantification, prior to injection into a gas chromatograph.

Extracts containing a high amount of waxes, e.g. the litter samples, were further cleaned up using columns filled with $1 \mathrm{~g}$ HR-P resin (polystyrene-divinylbenzene co-polymer, Macherey-Nagel, Dueren, Germany). After the sample was applied to the column, it was washed with $10 \mathrm{~mL}$ hexane before elution with $20 \mathrm{~mL}$ toluene. The eluate was evaporated at $65^{\circ} \mathrm{C}$ and 150 mbar.

A number (26) of the samples showed interfering peaks, caused by non-polar substances, during PCB measurement. These could be removed by a column filled with $9 \mathrm{~cm} \mathrm{33 \%}$ deactivated $\mathrm{NaOH}$-silica $[1 \mathrm{~cm}$ activated, $10 \mathrm{~cm} \mathrm{44 \%} \mathrm{deactivated}\left(\mathrm{H}_{2} \mathrm{SO}_{4}\right)$ and $2 \mathrm{~cm}$ $22 \%$ deactivated $\left(\mathrm{H}_{2} \mathrm{SO}_{4}\right)$ ]. PCBs were eluted with $60 \mathrm{~mL}$ of hexane, which was evaporated at $35^{\circ} \mathrm{C}$ and 280 mbar. This purification step has to be conducted after PAH measurement because these would be destroyed or sorbed by the column.

Table 1

Description of land-use classes ( $n=$ number of sampled sites)

\begin{tabular}{|c|c|c|c|c|}
\hline Land-use class & Abbreviation & $n$ & Sampling depth & Description \\
\hline Street & ST & 9 & $0-5 \mathrm{~cm}$ & Grass surface beside streets throughout whole city area \\
\hline Park & PA & 5 & $0-5 \mathrm{~cm}$ & $\begin{array}{l}\text { Corner and centre samples from Tundikhel, a rectangular green space } \\
\text { downtown, flanked by two highly frequented one way roads }\end{array}$ \\
\hline River sediment & RI & 5 & $0-5 \mathrm{~cm}$ & From Bagmati, Vishumati and Manahara rivers \\
\hline Industrial district & IN & 5 & $0-5 \mathrm{~cm}$ & $\begin{array}{l}\text { Grass surface next to the streets throughout Balaju Industrial District } \\
\text { in the northern part of Kathmandu }\end{array}$ \\
\hline Residential area & RE & 5 & $0-5 \mathrm{~cm}$ & $\begin{array}{l}\text { Residential area of Chauni in western part of Kathmandu; gardens or } \\
\text { grass surfaces beside streets }\end{array}$ \\
\hline Gutter & GU & 5 & $0-5 \mathrm{~cm}$ & $\begin{array}{l}\text { Gutter with no outlet, surrounding a closed metal factory; samples } \\
\text { taken at corners and at entry point of rain gutter }\end{array}$ \\
\hline Petrol station & $\mathrm{PE}$ & 5 & $0-5 \mathrm{~cm}$ & $\begin{array}{l}\text { Five petrol stations throughout the urban area; material scratched out } \\
\text { between road bricks }\end{array}$ \\
\hline Garden & GA & 3 & $\begin{array}{l}0-10,10-20,20- \\
30 \mathrm{~cm}\end{array}$ & $\begin{array}{l}\text { Three profiles, sampled in vegetable garden about } 1 \mathrm{~km} \mathrm{E} \text { of } \\
\text { Tribhuvan Airport }\end{array}$ \\
\hline Park II & SW & 3 & $\begin{array}{l}\text { litter, } 0-5,5-10 \\
10-15 \mathrm{~cm}\end{array}$ & $\begin{array}{l}\text { Three profiles, sampled at a wooded hill } 2 \mathrm{~km} \text { from centre } \\
\text { (Swayambunath temple) }\end{array}$ \\
\hline
\end{tabular}




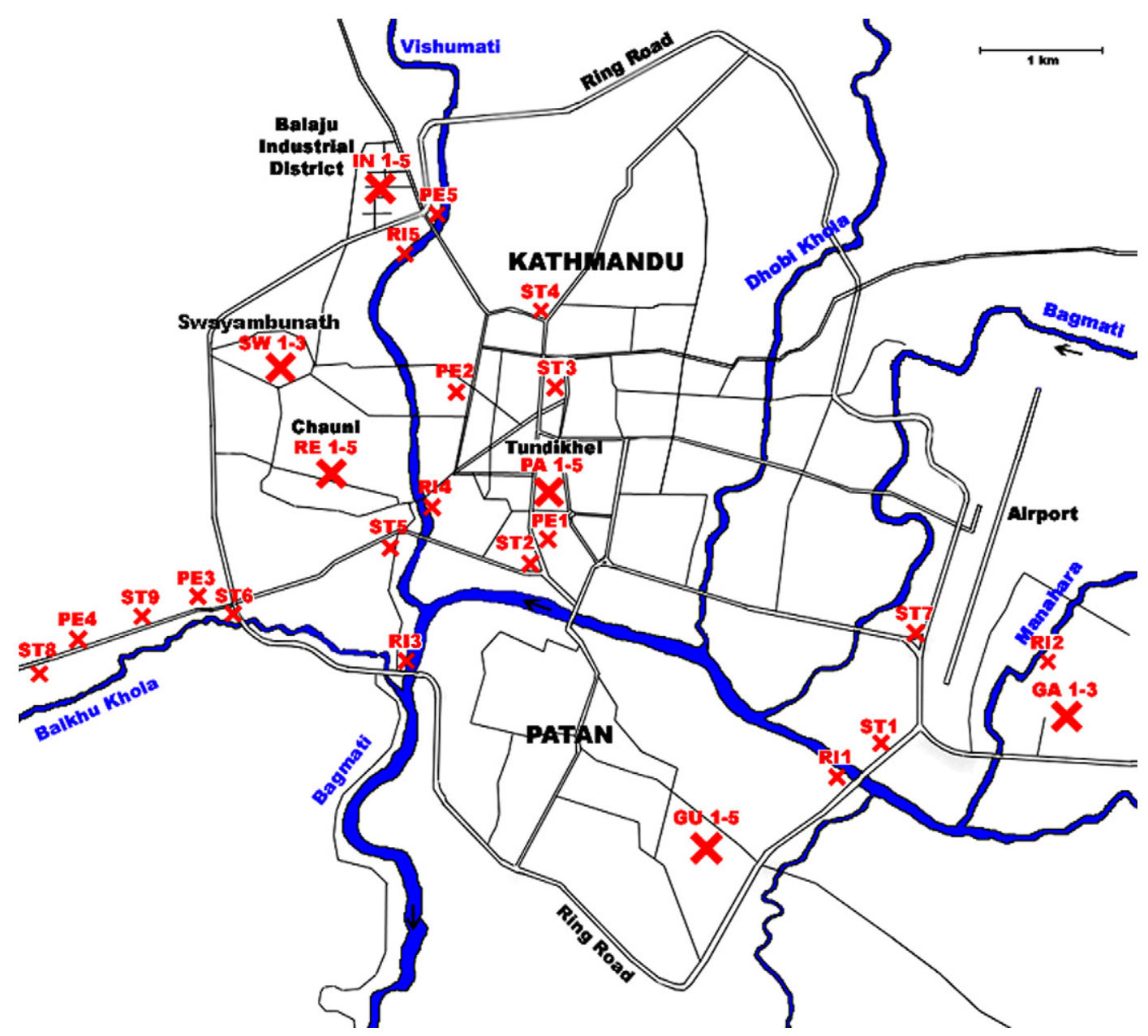

Fig. 1. Sampling sites. $\mathrm{RE}=$ residential area, $\mathrm{ST}=$ street, $\mathrm{RI}=$ river, $\mathrm{IN}=$ industrial district, $\mathrm{PE}=$ petrol station, $\mathrm{GU}=$ gutter, $\mathrm{PA}=$ park, $\mathrm{SW}=$ Swayambunath (park II), GA = garden

Measurements were conducted with an HP 5890 gas chromatograph, equipped with an HP 5-MS fused silica column of $30 \mathrm{~m}, 0.25 \mathrm{~mm}$ i.d. and $0.25 \mu \mathrm{m}$ film thickness. He $(99.7 \%)$ was used as carrier gas at a constant pressure of $80 \mathrm{kPA}$. For measurement, $1 \mu \mathrm{L}$ of purified extract was injected by an HP 5890 autosampler. The PAHs naphthalene (NAPH), acenaphthylene (ACY), acenaphthene (ACE), fluorene (FLU), phenanthrene (PHE), anthracene (ANT), fluoranthene (FLA), pyrene (PYR), benzo( $a$ )anthracene (BAA), chrysene + triphenylene (CT), benzo $(b+j+k)$ flouranthene (BBJK), benzo $(a)$ pyrene (BAP), benzo(e)pyrene (BEP), perylene (PER), indeno(1,2,3-cd)pyrene (IND), dibenzo $(a, h)$ anthracene (DBAH) and benzo $($ ghi $)$ perylene (BGHI), as well as PCB congeners 8, 20, 28, 35, 52, 101, 118, 138, 153, 180, 206, 209 (nos. according to Ballschmiter and Zell, 1980) were identified with a coupled HP 5971 A mass spectrometer using selected ion monitoring (SIM). The following temperature programmes were used: PAHs -4 min at $85^{\circ} \mathrm{C}, 15^{\circ} \mathrm{C} \mathrm{min}{ }^{-1}$ to $150^{\circ} \mathrm{C}$ (held $1.5 \mathrm{~min}$ ), to $300^{\circ} \mathrm{C}$ at $5^{\circ} \mathrm{C} \mathrm{min}{ }^{-1}$ (held $4 \mathrm{~min}$ ); PCBs $-2.7 \mathrm{~min}$ at $120^{\circ} \mathrm{C}, 10^{\circ} \mathrm{C} \mathrm{min}^{-1}$ to $190{ }^{\circ} \mathrm{C}$ (held $2 \mathrm{~min}$ ), to $250^{\circ} \mathrm{C}$ at $9{ }^{\circ} \mathrm{C} \mathrm{min}{ }^{-1}$ (held $1 \mathrm{~min}$ ), to $300^{\circ} \mathrm{C}$ at $14^{\circ} \mathrm{C} \mathrm{min}^{-1}$ (held $10 \mathrm{~min}$ ).

To eliminate background contamination, three blanks (Celite only) were extracted, purified, and analysed in the same way as the samples. Naphthalene was the only PAH detected. The mean concentration was substracted from sample concentrations. The results for naphthalene should generally be interpreted carefully, since considerable amounts can vaporize during air drying and may also contaminate other samples (Wilcke et al., 2003b). The PCB background contamination was 
more evident. The rarely used PCBs 35 and 209, as well as PCB 20, were not found in the blanks. The less-chlorinated PCBs 8, 20 and 52 were found in relatively small amount but some more chlorinated ones, especially congener 206, were more abundant. Recovery ranged from $62 \%$ to $107 \%$ for all PAHs, except naphthalene which had a lower recovery for samples purified with HR-P columns (12.3$16.9 \%$ ). This can be attributed to the fact that a high temperature and strong vacuum are needed for the evaporation of the elution solvent toluene, resulting in loss of the semi-volatile naphthalene. Recovery of the internal PCB standards was acceptable, ranging from $72 \%$ to $81 \%$.

\subsection{Compound specific $\delta^{13} \mathrm{C}$ analysis}

Six selected PAHs [PHE, BAP, BEP and PER, as well as benzo(b)flouranthene and benzo(k)flouranthene, BBK, which could not be separated] were analysed for their compound specific $\delta^{13} \mathrm{C}$ value. About $100 \mathrm{~g}$ of sample were extracted and purified as outlined above, except for addition of internal standards because of the insufficient separation of PAHs and their deuteriated counterparts and the resulting interference in compound specific $\delta^{13} \mathrm{C}$ determination. All extracts were additionally purified using solid phase extraction with $1 \mathrm{~g}$ HR-P resin. The gas chromatography-combustion-isotope ratio mass spectrometry (GC-C-IRMS) system consisted of a Trace GC 2000 gas chromatograph coupled to a Delta ${ }^{\text {Plus }}$ isotope ratio mass spectrometer (Thermoquest, Bremen, Germany) via a Thermoquest Finnigan GC Combustion III unit. PAH separation was carried out with a Hewlett-Packard 5-MS fused silica column $(60 \mathrm{~m}, 0.25 \mathrm{~mm}$ i.d., $0.25 \mu \mathrm{m}$ film thickness) with $\mathrm{He}(99.7 \%$ purity) as carrier gas (constant pressure mode, $80 \mathrm{kPA}$ ) and an injection volume of $1 \mu \mathrm{L}$ (splitless injection). For calibration, pulses of $\mathrm{CO}_{2}(99.7 \%$ purity, Riessner Gase, Lichtenfels, Germany) with an isotopic signature set at $-42 \%$, were discharged directly into the IRMS at defined times.

For identification of individual components via retention times and for correction of a potential amount-dependence of the isotopic signature, the samples had to be analysed in conjunction with external standards at different concentrations (Glaser and Amelung, 2002; Schmitt et al., 2003). The range of the external standard series was chosen to cover the calibration range of the measuring device and the concentration range of the samples.
The following concentrations were selected: 5,25 , 50, 100, 140 and $200 \mu \mathrm{g} \mathrm{mL}^{-1}$. Due to the lack of certificated standards for GC-C-IRMS, the $\delta^{13} \mathrm{C}$ values of the PAH standards were also measured via dry combustion with a Carlo Erba CN 2500 elemental analyser (EA), coupled to the same IRMS as the GC-C. To obtain accurate $\delta^{13} \mathrm{C}$ values, sucrose ANU (International Atomic Energy Agency (IAEA), Vienna, Austria) and $\mathrm{CaCO}_{3}$ (NBS 19, Gaithersburg, MD) were used as certificated calibration standards. Additionally, the bulk $\delta^{13} \mathrm{C}$ value of each soil sample was also measured using EA-IRMS. Each standard and sample were measured four times.

\subsection{Statistics}

To achieve normal distribution, the variables were $\log$ transformed. Normal distribution was tested with the Kolmogorov-Smirnov Test. Significance of differences in the mean values was tested with the Kruskal-Wallis Test. Correlations were tested using Pearson's correlation coefficient. The significance level in both tests was set to 0.05 . Cluster analysis of surface sample spots was performed with Ward's algorithm as linkage rule and the squared Euclidean distance as distance measure. To eliminate possible correlations between the variables, the cluster analysis was conducted with the factor loadings derived from a principal component analysis (PCA). PCA was conducted using factor extraction with an eigenvalue $>1$ after Varimax rotation. Significance was set to $p<0.05$.

\section{Results and discussion}

\section{1. $P A H$ and $P C B$ concentrations}

The amount of total PAHs in surface soils $(0-10 \mathrm{~cm}$ in garden profiles, $0-5 \mathrm{~cm}$ in other samples) ranges between 184 (sample industry 2) and 10279 (sample gutter 2) $\mu \mathrm{g} \mathrm{kg}^{-1}$, with an arithmetic mean of $1556 \mu \mathrm{g} \mathrm{kg}^{-1}$ (Table 2). Additionally, the sum of 16 reference PAHs by the Environmental Protection Agency (EPA-PAH) and the sum of combustion-derived PAHs (COMB-PAH) were calculated (Table 2). The latter are the higher condensed PAHs FLA, PYR, BAA, CHR, BBJK, BEP, BAP, IND and BGHI, which are mainly of pyrogenic origin (Hwang et al., 2003). The five ring PAH perylene is not considered as a combustion PAH as it is not thermally stable (Jiang et al., 2000). 
The concentrations of the sum of 12 PCBs in the surface soils ranges from 356 (sample garden 3 ) to 44710 (sample industry 1) $\mathrm{ng} \mathrm{kg}^{-1}$, with an arithmetic mean of $4965 \mathrm{ng} \mathrm{kg}^{-1}$ (Table 2). The sum of 6 indicator congeners $(28,52,101,138,153$, and 180) proposed by Ballschmiter and Zell (1980) and the sum of 7 EU indicator congeners $(28,52,101$, 118, 138, 153, and 180; Motelay-Massei et al., 2004) were also calculated. Some locations show both high PAH and PCB concentrations and can be regarded as "hot spots". This is especially the case for the gutter, which acts as a trap for pollutants, and the samples street 4 , street 9 , and industry 1. The high values of sample street 9 can be explained by contamination with used oil (e.g. hydraulic fluid), derived from the breakdown of old vehicles and machines for iron recycling. Remarkable is the influence of the city upon PCB concentrations in the river samples. Samples river 1 and river 2 (taken before the river enters the city) have considerably lower values than the other river samples. The maximum concentration was measured at sample river 4 , taken in the inner city. This demonstrates the abuse of the river as a rubbish dump and the relevance of waste containing PCBs, even several years after their prohibition.

Classified by land use, it is evident that the gutter shows significantly higher PAH and PCB concentrations than the other classes (Fig. 2), which can be easily explained by the accumulation of material washed off roofs. Industrial samples also exhibit high average PAH and PCB contents, while the large standard deviations are due to the high concentrations in sample industry 1 . The streets show also a tendency towards high PCB contents, but this contamination is rather inhomogeneous, as indicated by a high standard deviation. Petrol station, park, residential area and river samples show intermediate amounts of pollution. Lowest concentrations occur in the surface samples from the garden and Swayambunath profiles. Swayambunath samples show a steady decrease in PAH and PCB concentration with depth. The three profiles are contaminated to a similar level with PCBs, which can be seen in the low standard deviations. On the other hand, no significant trend is visible at the garden site. Swayambunath is a hill, with forest covering undisturbed soil. In contrast, the soil is regularly turned over and used for agriculture in the garden, which results in irregular pollutant concentrations. All garden samples, especially garden 3 at 20 $30 \mathrm{~cm}$ depth, showed remarkable differences in the sum of 20 PAHs and EPA values due to elevated perylene concentrations.

In the surface soils, perylene is the dominant $\mathrm{PAH}$, with an average of $14.6 \%$, followed by benzo $(b+j+k)$ flouranthene $(10.7 \%)$, naphthalene $(10.7 \%)$ and phenanthrene $(9.8 \%)$. However, the proportions of perylene vary strongly (Fig. 3). PCB $52(19.4 \%)$ is the most abundant PCB, followed by congeners $101(14.3 \%), 118(13.4 \%)$ and $138(11.7 \%)$. In general, the standard deviation is quite high for all PCBs, which can be a result of the different degradation behaviour of the single congeners under different conditions.

Concerning PCA with surface soil samples, two principal components (PCs) with an eigenvalue $>1$ were extracted for PAHs (explaining $82.6 \%$ of the total variance, with values for $\mathrm{PC} 1$ and $\mathrm{PC} 2$ of $60.3 \%$ and $22.3 \%$ respectively) and four $\mathrm{PCs}$ [explaining 45.2\% (PC1), 17.4\% (PC2), 12.4\% (PC3) and $9.6 \%$ (PC4) of the total variance] for PCBs. Fig. 4 shows the factor loadings of the first two components. The PAHs FLA, CT, BAA, BEP, BAP, BGHI, BBJK, DBAH and IND, which are identical with the combustion derived PAHs, are loaded mainly by component 1 . FLU and ACE are loaded by component 2 . The other two and three ring PAHs NAPH, ACY, ANT and PHE, as well as the four ring PYR, are partially loaded by both components. PER has negative loading for both components. PCBs 8, 20, 52, 101, 118, 138, and 153 are loaded by PC1, the congeners 28 and 180 by PC2. PCBs 35, 206 and 209 do not occur or are only in traces in commercial PCB mixtures (Frame et al., 1996; Eckrich, 1996). Their rare use is reflected by low or negative factor loadings of the principal components.

\subsection{Source identification of PAHS}

Molecular compositions of PAHs depend on factors such as parent material, combustion temperature and air to fuel ratio (Okuda et al., 2002a). Therefore, their characteristic spectrum can be used as a fingerprint to identify sources (Khalili et al., 1995). PAH ratios have been widely used to detect combustion-derived components. Fresh liquid fuels (petrogenic sources) are normally abundant in lower molecular weight PAHs, while combustion residues (pyrogenic sources) contain higher molecular weight PAHs (Zakaria et al., 2002; Chen et al., 2005). The ratio COMB/EPA has been described to be on average 0.7 for PAHs of pyrogenic source (Hwang et al., 
Table 2

PAH $\left(\mu \mathrm{g} \mathrm{kg}^{-1}\right)$ and PCB $\left(\mathrm{ng} \mathrm{kg}^{-1}\right)$ concentrations and PAH ratios

\begin{tabular}{|c|c|c|c|c|c|c|c|c|}
\hline Sample & $\sum 20 \mathrm{PAH}$ & $\sum E P A-P_{A H}^{a}$ & $\sum \mathrm{COMB}^{\mathrm{b}}$ & $\sum 12 \mathrm{PCB}$ & $\sum 6 \mathrm{PCB}^{\mathrm{c}}$ & $\sum E U-P C B^{d}$ & $\mathrm{COMB} / \mathrm{EPA}$ & $\overline{\mathrm{PER} / \sum 20 \mathrm{PAH}}$ \\
\hline RE1 & 1917 & 145 & 134 & 1207 & 580 & 862 & 0.93 & 0.91 \\
\hline RE2 & 608 & 533 & 421 & 992 & 599 & 892 & 0.79 & 0.04 \\
\hline RE3 & 344 & 299 & 270 & 1583 & 1583 & 1583 & 0.90 & 0.04 \\
\hline RE4 & 571 & 485 & 442 & 2198 & 2122 & 2122 & 0.91 & 0.05 \\
\hline RE5 & 508 & 468 & 309 & 1691 & 1355 & 1571 & 0.66 & 0.02 \\
\hline PA1 & 1341 & 1150 & 1064 & 1131 & 567 & 811 & 0.93 & 0.05 \\
\hline PA2 & 1050 & 943 & 778 & 1445 & 610 & 995 & 0.83 & 0.02 \\
\hline PA3 & 1453 & 1258 & 1223 & 2061 & 1169 & 1787 & 0.97 & 0.01 \\
\hline PA4 & 779 & 695 & 664 & 400 & 168 & 307 & 0.96 & 0.01 \\
\hline PA5 & 1218 & 1097 & 932 & 6301 & 2968 & 5561 & 0.85 & 0.01 \\
\hline ST1 & 312 & 270 & 196 & 2085 & 734 & 1636 & 0.73 & 0.08 \\
\hline ST2 & 912 & 814 & 703 & 6668 & 6487 & 6487 & 0.86 & 0.03 \\
\hline ST3 & 841 & 777 & 582 & 5184 & 3203 & 3203 & 0.75 & 0.03 \\
\hline ST4 & 1991 & 1830 & 1680 & 9175 & 4713 & 4943 & 0.92 & 0.02 \\
\hline ST5 & 716 & 650 & 417 & 4915 & 2088 & 2088 & 0.64 & 0.05 \\
\hline ST6 & 793 & 732 & 465 & 4930 & 2849 & 2849 & 0.64 & 0.03 \\
\hline ST7 & 207 & 160 & 129 & 717 & 309 & 409 & 0.80 & 0.18 \\
\hline ST8 & 1725 & 1576 & 1224 & 5539 & 5059 & 5539 & 0.78 & 0.02 \\
\hline ST9 & 1254 & 1171 & 597 & 12563 & 11837 & 11837 & 0.51 & 0.01 \\
\hline PE1 & 3058 & 2982 & 1195 & 5495 & 4703 & 5495 & 0.40 & 0.01 \\
\hline PE2 & 573 & 522 & 350 & 1829 & 1829 & 1829 & 0.67 & 0.04 \\
\hline PE3 & 1479 & 1437 & 783 & 1172 & 1172 & 1172 & 0.54 & 0.01 \\
\hline PE4 & 1612 & 1566 & 853 & 4576 & 3313 & 4047 & 0.54 & 0.01 \\
\hline PE5 & 1233 & 1190 & 734 & 3579 & 2389 & 2759 & 0.62 & 0.02 \\
\hline GU1 & 2956 & 2765 & 1803 & 8073 & 5881 & 6260 & 0.65 & 0.01 \\
\hline GU2 & 10279 & 9234 & 8422 & 19697 & 12146 & 14573 & 0.91 & 0.01 \\
\hline GU3 & 5405 & 4966 & 4006 & 17012 & 12420 & 15291 & 0.81 & 0.01 \\
\hline GU4 & 3139 & 2885 & 2256 & 6341 & 3838 & 4367 & 0.78 & 0.01 \\
\hline GU5 & 4440 & 4172 & 3013 & 8005 & 5332 & 6129 & 0.72 & 0.01 \\
\hline RI1 & 1060 & 490 & 355 & 769 & 769 & 769 & 0.73 & 0.52 \\
\hline RI2 & 833 & 149 & 98 & 741 & 377 & 535 & 0.66 & 0.81 \\
\hline RI3 & 902 & 660 & 402 & 4598 & 3236 & 3615 & 0.61 & 0.24 \\
\hline RI4 & 1079 & 926 & 481 & 7035 & 4951 & 5531 & 0.52 & 0.12 \\
\hline RI5 & 1669 & 964 & 410 & 4222 & 3726 & 4002 & 0.42 & 0.41 \\
\hline IN1 & 6899 & 6273 & 5671 & 44710 & 35408 & 40316 & 0.90 & 0.02 \\
\hline IN2 & 184 & 136 & 85 & 832 & 745 & 745 & 0.62 & 0.21 \\
\hline IN3 & 746 & 414 & 340 & 1831 & 1587 & 1587 & 0.82 & 0.31 \\
\hline IN4 & 468 & 416 & 238 & 2233 & 1446 & 1601 & 0.57 & 0.04 \\
\hline IN5 & 548 & 476 & 312 & 3411 & 3291 & 3291 & 0.66 & 0.07 \\
\hline GA1 $0-10$ & 490 & 171 & 139 & 385 & 129 & 236 & 0.81 & 0.61 \\
\hline GA1 10-20 & 699 & 271 & 183 & 388 & 110 & 210 & 0.67 & 0.57 \\
\hline GA1 20-30 & 653 & 252 & 210 & 453 & 190 & 353 & 0.83 & 0.57 \\
\hline GA2 0-10 & 754 & 172 & 168 & 875 & 419 & 823 & 0.98 & 0.75 \\
\hline GA2 10-20 & 449 & 224 & 159 & 777 & 318 & 626 & 0.71 & 0.45 \\
\hline GA2 $20-30$ & 979 & 362 & 315 & 1819 & 583 & 974 & 0.87 & 0.58 \\
\hline GA3 0-10 & 427 & 182 & 155 & 268 & 132 & 240 & 0.86 & 0.52 \\
\hline GA3 10-20 & 559 & 286 & 266 & 373 & 141 & 141 & 0.93 & 0.43 \\
\hline GA3 20-30 & 2311 & 677 & 781 & 1184 & 626 & 821 & 1.15 & 0.64 \\
\hline SW1 L & 807 & 588 & 420 & 4305 & 2631 & 3515 & 0.71 & 0.25 \\
\hline SW1 0-5 & 351 & 309 & 233 & 1374 & 907 & 1019 & 0.75 & 0.06 \\
\hline SW1 5-10 & 328 & 204 & 153 & 1115 & 743 & 970 & 0.75 & 0.33 \\
\hline SW1 10-15 & 142 & 102 & 79 & 475 & 366 & 475 & 0.78 & 0.20 \\
\hline SW2 L & 1079 & 862 & 542 & 5325 & 2328 & 2655 & 0.63 & 0.18 \\
\hline SW2 0-5 & 433 & 382 & 282 & 1925 & 1025 & 1534 & 0.74 & 0.07 \\
\hline SW2 5-10 & 291 & 250 & 182 & 856 & 536 & 604 & 0.73 & 0.06 \\
\hline SW2 10-15 & 138 & 107 & 72 & 714 & 552 & 589 & 0.67 & 0.15 \\
\hline SW3 L & 851 & 823 & 550 & 5924 & 3267 & 3901 & 0.67 & 0.01 \\
\hline
\end{tabular}


Table 2 (continued)

\begin{tabular}{|c|c|c|c|c|c|c|c|c|}
\hline Sample & $\sum 20 \mathrm{PAH}$ & $\sum E P A-P A H^{\mathrm{a}}$ & $\sum \mathrm{COMB}^{\mathrm{b}}$ & $\sum 12 \mathrm{PCB}$ & $\sum 6 \mathrm{PCB}^{\mathrm{c}}$ & $\sum E U-P^{2} B^{d}$ & COMB/EPA & $\mathrm{PER} / \sum 20 \mathrm{PAH}$ \\
\hline SW3 0-5 & 455 & 392 & 303 & 1630 & 1088 & 1277 & 0.77 & 0.07 \\
\hline SW3 5-10 & 307 & 240 & 226 & 1210 & 785 & 1071 & 0.94 & 0.10 \\
\hline SW3 $10-15$ & 308 & 221 & 222 & 858 & 511 & 691 & 1.01 & 0.14 \\
\hline
\end{tabular}

a NAPH, ACY, ACE, FLU, PHE, ANT, FLA, PYR, BAA, CHR, BB, BK, BAP, IND, BGHI and DBAH.

${ }^{\mathrm{b}} \mathrm{COMB}-\mathrm{PAH}=\mathrm{FLA}, \mathrm{PYR}, \mathrm{BAA}, \mathrm{CHR}, \mathrm{BBJK}, \mathrm{BEP}, \mathrm{BAP}, \mathrm{IND}$ and BGHI.

c $28+52+101+138+153+180$.

d 6 PCBs +118 .

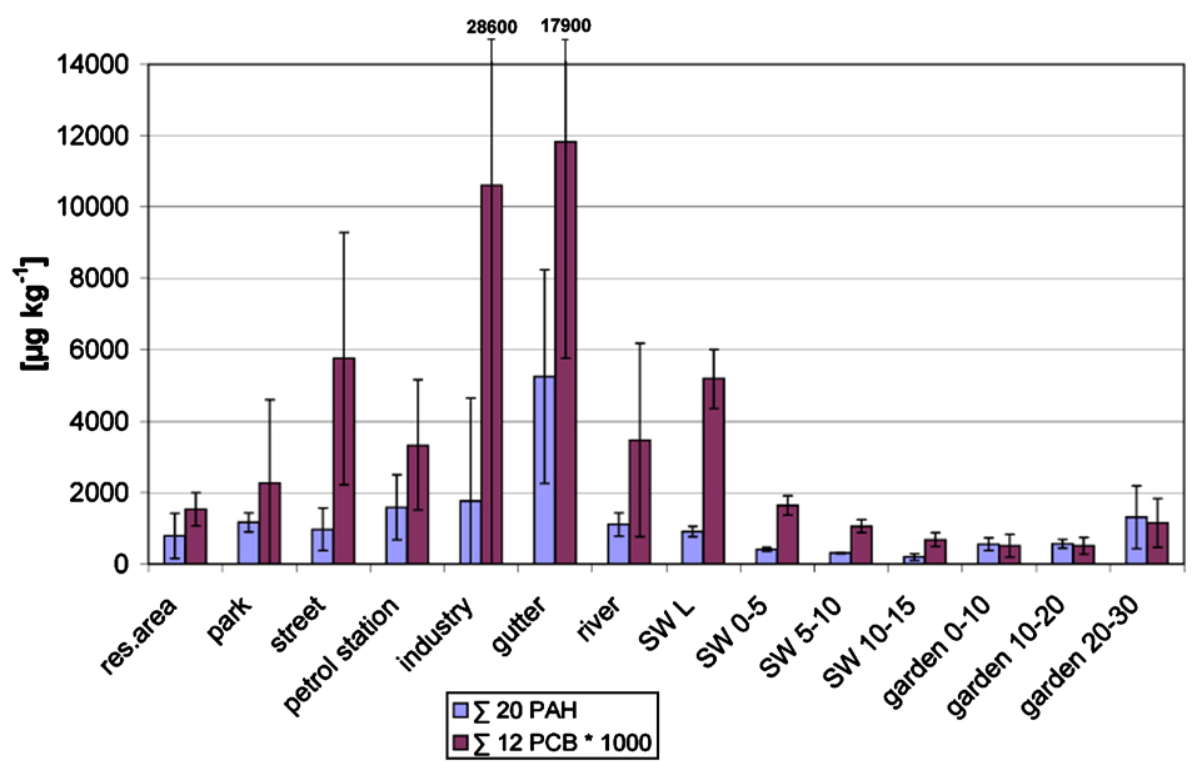

Fig. 2. Average PAH and PCB concentrations and standard deviations for samples classified by land-use.

2003). Samples with a ratio $<0.6$ are street 9 , petrol station samples 1,3 and 4, river samples 4 and 5 and industry sample 4 (Table 2), which gives a hint that these samples are influenced by petrogenic $\mathrm{PAH}$ sources.

On average, samples contain between $1 \%$ and $7 \%$ perylene (Table 2) while some show significantly higher proportions. Elevated perylene contributions were found for the garden samples, some of the river sediments and Swayambunath samples, and, most of all, in the residential area sample 1, with a maximum of $91.7 \%$ (Table 2). The result of the PCA also emphasizes the special role of perylene in the PAH pattern of the soils (Fig. 4).

Perylene is not present or occurs only in small amount in the products of combustion processes, probably due to its thermal instability or reactivity (Jiang et al., 2000), but there is also significant evidence that it can be produced biologically under anaerobic conditions (Venkatesan, 1988; Thiele and Brümmer, 2002). Perylene quinones (pigments found in several insects, plants or fungi) are suspected to be degraded to perylene by anaerobic microbial metabolism (Jiang et al., 2000; Wilcke et al., 2002). Another theory postulates production via biosynthesis, independent of special precursors (Wilcke et al., 2002).

The ${ }^{13} \mathrm{C}$ signature of PAHs can be used as a tool for assessing their sources, as it usually resembles the signature of combusted material (Okuda et al., 2002a). It is, however, very difficult to identify the exact source, because the $\delta^{13} \mathrm{C}$ values of fuels are not distinct (Mandalakis et al., 2004) and they can be influenced by temperature of combustion (McRae et al., 1999). For instance, coal ( $-25 \%$ to $-31 \%$; McRae et al., 1999; Sun et al., 2003), 

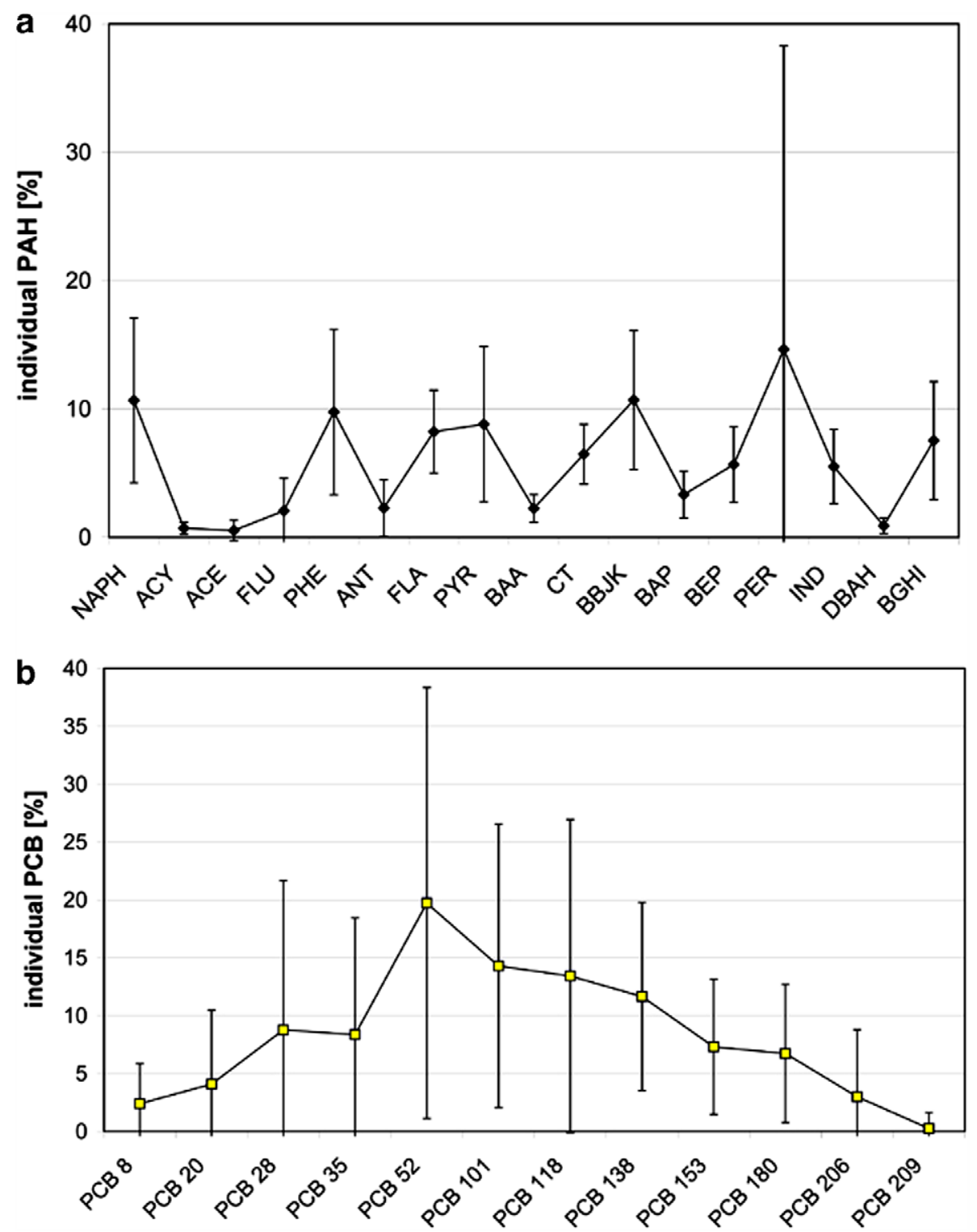

Fig. 3. Average percentage and standard deviation of individual (a) PAHs and (b) PCBs in surface samples $(n=45)$.

gasoline $(-19 \%$ to $-30 \%$; Okuda et al., 2002b; Sun et al., 2003) and wood burning smoke $(-26.8 \%$ to $-31.6 \%$; Okuda et al., 2002b; O’Malley et al., 1997) all cover a considerable, and more or less the same, range of $\delta^{13} \mathrm{C}$ values. The isotope signature of organic compounds is also altered during microbial metabolism (Mariotti and Balesdent, 1990). However, given the relatively large size of the molecule, this isotopic shift should be quite small in biodegradation of perylene quinones. Combustion-derived PAHs are deposited from the atmosphere and are independent of the isotopic composition of the soil, while biologically produced PAHs should reflect the signal of the carbon source. If this carbon source is influenced by material derived from $\mathrm{C}_{4}$ plants, than it should be possible to distinguish PAHs of biological origin from pyrogenic PAHs by the isotopic signature.

To test this hypothesis, five samples containing elevated perylene concentrations and five with normal perylene levels were chosen for compound specific $\delta^{13} \mathrm{C}$ analysis. In addition to perylene, the typical combustion-derived PAHs BAPBEP, ben$\mathrm{zo}(b)$ - and benzo $(k)$ flouranthene (BBK, because 

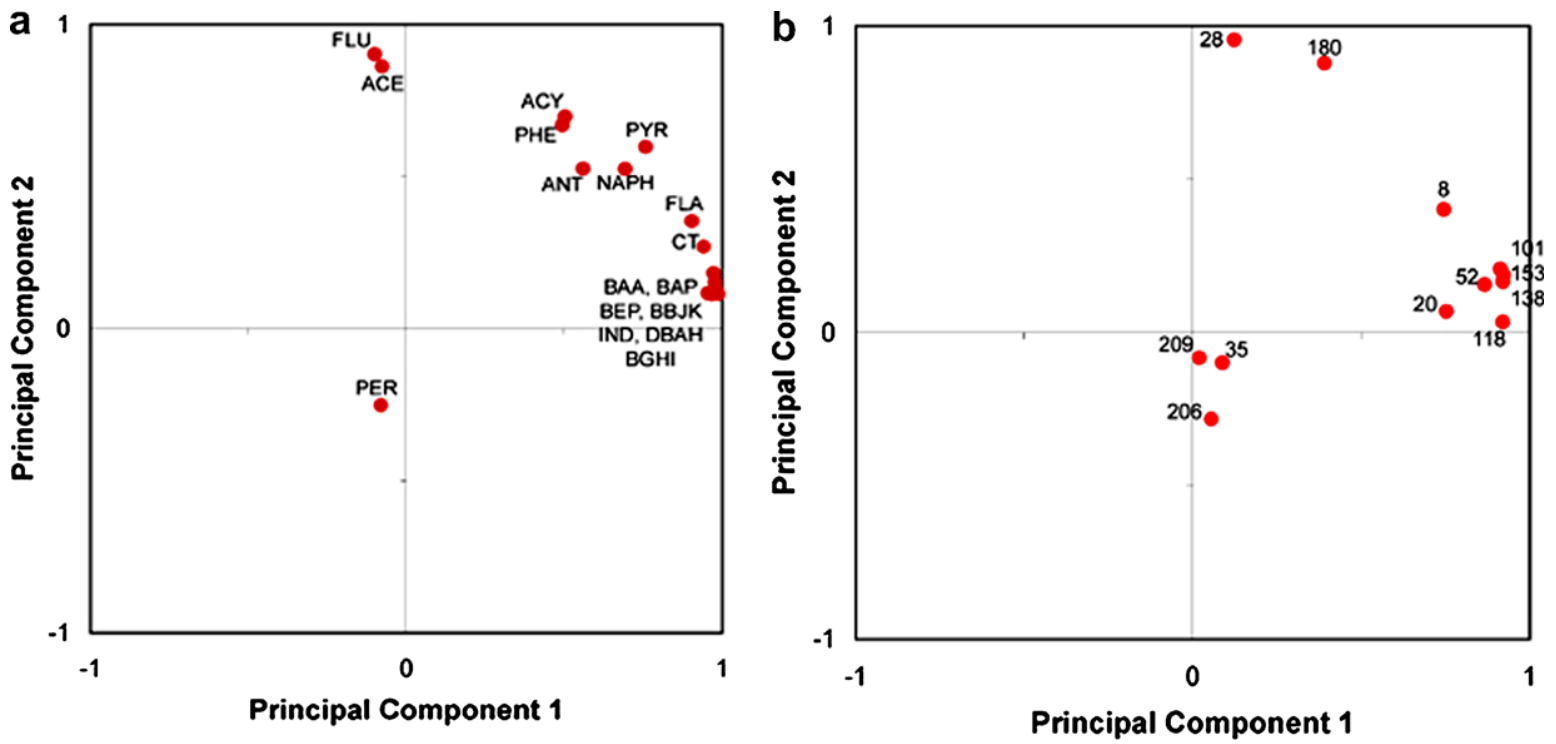

Fig. 4. Diagrams of factor loadings of principal components for (a) PAHs and (b) PCBs in surface soils $(n=45)$.

the peaks could not be separated from each other) were analysed. As PHE is another PAH suspected to be produced biologically (Krauss et al., 2005; Atanassova and Brümmer, 2004), it was also included in the analysis. Decisive for selection of samples was that they contained sufficient amounts of each PAH to provide chromatographic peaks suitable for $\delta^{13} \mathrm{C}$ evaluation. This was difficult, as especially for samples with very high perylene content (e.g. sample residential area 1) the pyrogenic $\mathrm{PAH}$ concentrations were very low, resulting in some missing values.

Table 3 shows the $\delta^{13} \mathrm{C}$ values for individual PAHs as well as those for bulk soils. The varying bulk values suggest a changing influence of $\mathrm{C}_{3}$ and $\mathrm{C}_{4}$ vegetation, dependent on location. The values for benzo $(b+k)$ fluoranthene, $\operatorname{benzo}(a)$ pyrene and benzo(e)pyrene ranged between $-20.7 \%$ and $-29.6 \%$, within the normal range for combustionderived PAHs. Also, the values for perylene at locations with non-elevated concentrations, and of phenanthrene were within this range. The perylene values are significantly more positive for samples with high perylene content, while isotopic signatures of the other PAHs do not differ much from each other. Especially for the garden samples, perylene is strongly enriched in ${ }^{13} \mathrm{C}$, unlike the other samples, which could be a hint of a biological production. The garden is situated on the first terrace, several meters above the water level of the Manahara river in the dry season. It is unlikely, even during mon- soon, that the groundwater level rises so high that periodical anaerobic conditions lead to biological perylene production. However, crop rotation with growing vegetables, wheat, maize, barley, or potatoes in the dry season and wetland rice in the monsoon season is a common practice in the Kathmandu Valley (Müller, 1981). At the time of sampling, different kind of vegetables were grown on the field and no information on the further agricultural use could be received from the farmer but, in all probability, the perylene in the garden soils is a leftover of biological production, caused by the practice of crop rotation.

Anaerobic conditions occur in the river sediments, so it is likely that perylene was also produced biologically there. The situation is unclear for the residential area sample 1 . The isotope signature gives no additional hint of sources, since all PAHs and the bulk ${ }^{13} \mathrm{C}$ signature are at the same level. However, a pyrogenic source of perylene can be excluded due to the high concentration in the sample. Remarkable is the fact that sample residential area 1 was taken at a spot where soil material, removed for the purpose of house construction, was deposited. So, it is quite possible that it derived from deeper, groundwater-influenced soil horizons with anaerobic conditions.

In general, a biological production of perylene by degradation of perylene quinones or other organic substances is plausible, at least for the garden and river samples and sample residential area 1. The 
Table 3

$\delta^{13} \mathrm{C}$ values $(\delta \%$ ) of bulk soil and selected PAHs in selected samples with elevated (upper part) and non-elevated (lower part) perylene concentrations

\begin{tabular}{|c|c|c|c|c|c|c|}
\hline & BULK & PHE & BBK & BEP & BAP & PER \\
\hline RI5 & -23.5 & -24.9 & -24.6 & -23.9 & -24.8 & -21.3 \\
\hline RE1 & -21.7 & n.q. ${ }^{\mathrm{a}}$ & -20.7 & n.q. & n.q. & -20.4 \\
\hline GA2 0-10 & -24.3 & -25.8 & -24.1 & -23.8 & -25.7 & -17.4 \\
\hline GA2 20-30 & -24.5 & -26.0 & -24.4 & -21.4 & -22.7 & -16.0 \\
\hline GA3 20-30 & -23.8 & -26.8 & -24.8 & -24.5 & n.q. & -15.8 \\
\hline $\mathrm{AM}$ & -23.6 & -25.9 & -23.7 & -24.3 & -24.4 & -18.1 \\
\hline STD & 1.1 & 0.8 & 1.7 & 1.4 & 1.6 & 2.5 \\
\hline IN1 & -25.1 & -26.7 & -27.3 & -26.8 & -27.8 & -26.2 \\
\hline PA1 & -17.8 & -25.0 & -23.4 & -22.5 & -24.2 & -26.0 \\
\hline PA3 & -15.9 & -24.5 & -24.1 & -23.5 & -24.2 & -23.2 \\
\hline GU2 & -24.6 & -26.6 & -24.8 & -23.8 & -25.7 & -25.6 \\
\hline ST4 & -19.6 & -23.7 & -26.1 & -29.6 & -25.3 & -28.9 \\
\hline $\mathrm{AM}^{\mathrm{b}}$ & -20.6 & -25.3 & -25.1 & -25.2 & -25.4 & -26.0 \\
\hline $\mathrm{STD}^{\mathrm{c}}$ & 4.1 & 1.3 & 1.6 & 2.9 & 1.5 & 2.0 \\
\hline
\end{tabular}

a n.q. = not quantified, too low signal.

b Arithmetic mean.

c Standard deviation.

higher concentrations in the deeper layers of the Swayambunath samples (Table 2) can be explained by groundwater influence. The reason for the relatively high concentration in sample street 7 is probably the result of the morphology of the sample spot, a kind of basin where several rain gutters end and which is, according to residents, completely flooded in the monsoon. Difficult to explain are the elevated concentrations in the litter samples from Swayambunath and in the industry samples 2 and 3.

Three groups can be distinguished using hierarchical cluster analysis based on PAH concentration (Fig. 5). Clearly separated from the other samples are the garden surface samples, all river samples except 4 , industry 2 and 3 , street 7 and residential area 1 (group 3). Group 1 and 2 are of closer distance to each other. Group 1 contains all Swayambunath surface samples, all petrol station samples, all gutter samples except 2, street samples 3, 5, 6, 9 and samples residential area 5 , river 4 , industry 4 and 5 . Group 2 contains all park samples, as well as street samples $1,2,4,8$, residential area samples 2, 3, 4, samples industry 1 and gutter 2 . The group 3 samples differ from the others by way of elevated perylene concentrations and are therefore influenced by biological PAH sources. The PAH pattern of group 1 is influenced by PAH sources of petrogenic origin, while samples in group 2 are dominated by pyrogenic PAHs.

\subsection{Source identification of $P C B$ s}

PCBs were never used as single compounds but as technical mixtures. The fingerprint of Kathmandu soils does not resemble any distinct PCB mixture: $70 \%$ of the PCBs produced globally were tri-, tetra- and pentachlorinated biphenyls, with trichlorinated ones as dominating homologues (Breivik et al., 2002). Thus, the PCB pattern of Kathmandu possibly reflects the background contamination of ubiquitous PCBs.

The low values of trichlorobiphenyls 20 and 28 can be explained by their preferred microbial degradation and volatilization. The rarely used congeners 35 and 206 can be found in considerable amounts in some samples. Some microorganisms are able of dechlorinating highly chlorinated PCBs via chlororespiration under anaerobic conditions, leaving lower chlorinated PCBs as residues (Abraham et al., 2002). PCB 35 is especially abundant in sample street 7. This can be described by the location of the sampling spot in a regularly flooded basin. Recently, PCB 35 was found in the effluent from a pigment manufacturer and in the surrounding surface waters in New York Harbour (Litten et al., 2002). This could also be a source for the congener in the Kathmandu Valley, as pigments definitively play an important role in Nepal's textile and garment industry. As PCB 35 is not included in most 


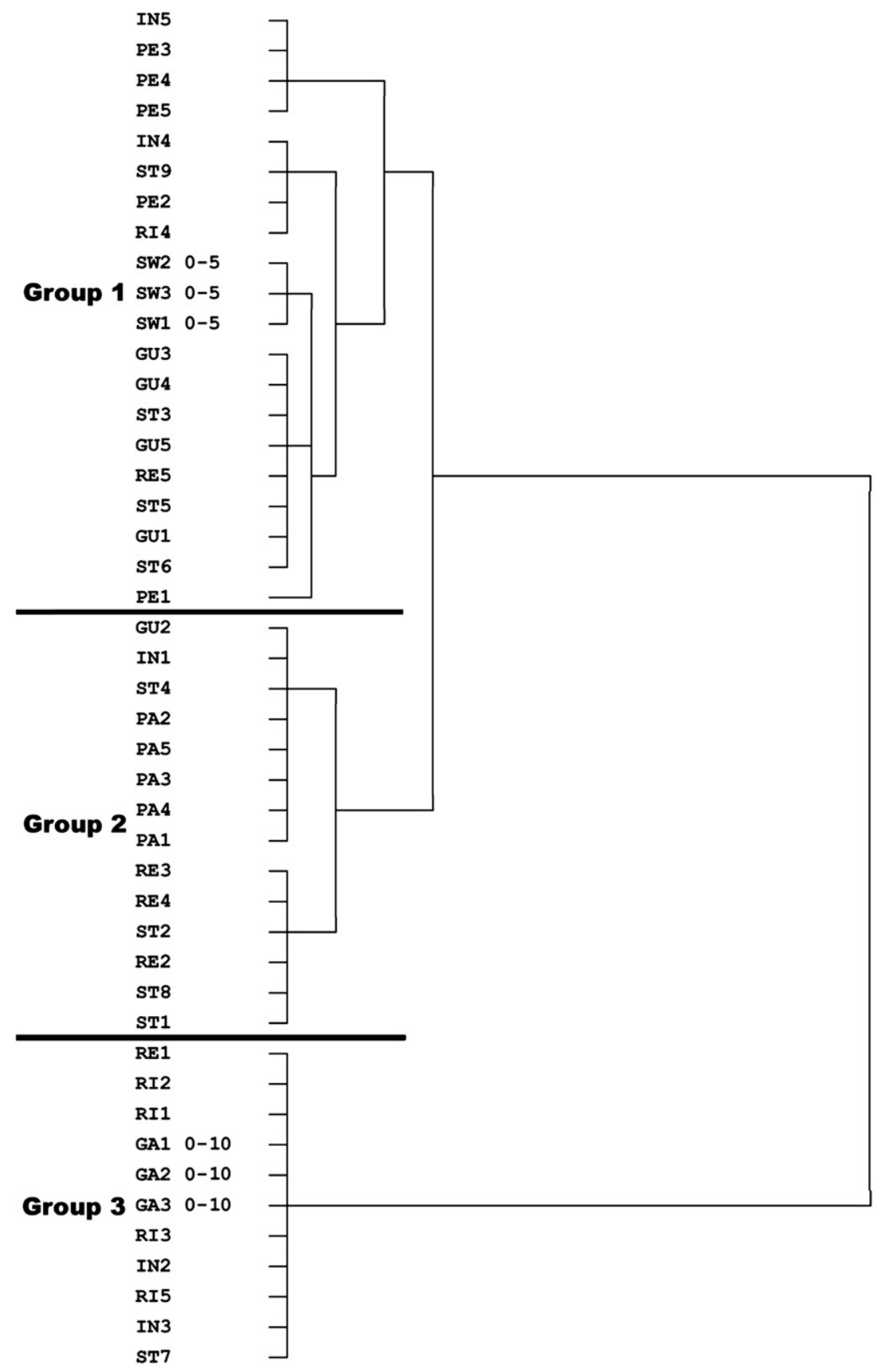

Fig. 5. Dendrogram of cluster analysis for sampling sites based on PAH concentrations in surface samples $(0-5 \mathrm{~cm})$.

studies and monitoring programmes, more research is necessary to confirm this potentially novel PCB source. The high contents of PCB 206 are probably caused by background contamination in the laboratory.

From hierarchical cluster analyses based on PCB concentrations, only two groups were obtained, the first of which contains 35 samples (data not shown).
This confirms the suspicion that PCBs in the Kathmandu soils originate from a diffuse background contamination. Petrol station samples (except sample 4), street 2 and 5, industry 3 and 5, and gutter 1 and 3 are assigned to group 2. The reason for the separation is unclear, because there are no remarkable differences detectable in the PCB patterns of those samples. 


\subsection{Contamination level in a global context}

There exist several reference values for the classification of soil contamination. The New Dutch List (Leidraad Bodemsanering) of 1994 is a common reference applied in mid-Europe (in Eusterbrock, 1999). It uses the sum of 13 PAHs (NAPH + $\mathrm{PHE}+\mathrm{ANT}+\mathrm{FLA}+\mathrm{BAA}+\mathrm{CT}+\mathrm{BBJK}+\mathrm{BAP}$ $+\mathrm{IND}+\mathrm{BGHI})$ and that of $7 \mathrm{PCB}$ congeners $(28+52+101+118+138+153+180)$ proposed by the EU as indicator substances. Other reference values are given by the Bodenschutzgesetz BadenWürttemberg (BodSchG BW) or the EikmannKloke-List (in Eusterbrock, 1999). The average values for Kathmandu of $\sum 13 \mathrm{PAH}$ and BAP are in the range of background values according to the New Dutch List, the BodSchG BW or the Eikmann-Kloke-List. The maximum values are much lower than intervention or inspection values. Average values for PCBs are below reference background values and maximum values are 2-3 times higher.

Table 4 contains a comparison of PAH and PCB results for Kathmandu with studies conducted for Bangkok, Thailand (Müller, 1998), Uberlândia,
Brazil (Wilcke et al., 1999a), Beijing, China (Ma et al., 2005), Romania (samples from Bucharest, Timisoara, Arad, Baia Mare, Ploiesti, Calimanesti; Covaci et al., 2001), several towns in the Seine Basin, France (Motelay-Massei et al., 2004), Bayreuth, Germany (Eusterbrock, 1999), Hamburg, Germany (Institut für Hygiene und Umwelt, 2001) and Stockholm, Sweden (Mandalakis et al., 2004). The 20 PAHs measured in Stockholm include three alkyl PAHs instead of NAPH, ACY and ACE. The EPA PAHs measured for the Seine-Basin lack NAPH and ACY. In Stockholm only lake and river sediments were sampled. In Romania, in addition to the 7 EU indicator PCBs, 12 less important PCBs were measured.

In general, a trend of increasing pollution with latitude is visible. Accordingly, Kathmandu fits well into a global distribution pattern of organic pollutants, with low concentrations in the tropics - despite high actual pollution - and high ones in temperate regions. In warm/humid climates, microbial degradation and volatilization seem to attenuate a high input into the soil. Additionally, the relatively high altitude of the Kathmandu Valley, which probably leads to an acceleration of photodegradation, has

Table 4

Comparison of PAH $\left(\mu \mathrm{g} \mathrm{kg}^{-1}\right)$ and PCB concentrations $\left(\mathrm{ng} \mathrm{kg}^{-1}\right)$ at different locations $(n=$ number of samples)

\begin{tabular}{|c|c|c|c|c|c|c|c|c|}
\hline & & Uberlândia $^{a}$ & Bangkok $^{\mathrm{b}}$ & Kathmandu & Beijing $^{c}$ & France $^{\mathrm{d}}$ & Bayreuth $^{\mathrm{e}}$ & Stockholm $^{f}$ \\
\hline$n$ & & 18 & 9 & 45 & 47 & 37 & 25 & 18 \\
\hline Latitude & & $19^{\circ} 50^{\prime} \mathrm{S}$ & $13^{\circ} 38^{\prime} \mathrm{N}$ & $27^{\circ} 40^{\prime} \mathrm{N}$ & $39^{\circ} 48^{\prime} \mathrm{N}$ & $\approx 49^{\circ} \mathrm{N}$ & $49^{\circ} 47^{\prime} \mathrm{N}$ & $59^{\circ} 21^{\prime} \mathrm{N}$ \\
\hline \multirow[t]{2}{*}{$\sum 20 \mathrm{PAH}$} & $\mathrm{AM}$ & 118 & 160 & 1556 & n.d. ${ }^{\mathrm{i}}$ & n.d. & 4244 & 11813 \\
\hline & STD & 197 & 116 & 1908 & n.d. & n.d. & 5168 & 15470 \\
\hline \multirow[t]{3}{*}{$\sum$ EPA-PAH } & $\mathrm{AM}$ & n.i. ${ }^{j}$ & n.i & 1371 & 1347 & 2510 & n.i. & n.i \\
\hline & STD & n.i. & n.i & 1778 & 995 & 1009 & n.i. & n.i. \\
\hline & & Uberlândia & Bangkok & Kathmandu & Romania $^{\mathrm{g}}$ & France & Bayreuth & Hamburg $^{\mathrm{h}}$ \\
\hline$n$ & & 18 & 9 & 45 & 13 & 37 & 25 & 18 \\
\hline Latitude & & $19^{\circ} 50^{\prime} \mathrm{S}$ & $13^{\circ} 38^{\prime} \mathrm{N}$ & $27^{\circ} 40^{\prime} \mathrm{N}$ & $\approx 45^{\circ} \mathrm{N}$ & $\approx 49^{\circ} \mathrm{N}$ & $49^{\circ} 47^{\prime} \mathrm{N}$ & $53^{\circ} 31^{\prime} \mathrm{N}$ \\
\hline \multirow[t]{2}{*}{$\sum 12$ РСВ } & $\mathrm{AM}$ & 341 & 1929 & 4965 & 57300 & n.d & 12115 & n.d \\
\hline & STD & 342 & 3652 & 7358 & 41000 & n.d & 9938 & n.d \\
\hline \multirow{2}{*}{$\sum E U-P C B$} & $\mathrm{AM}$ & n.i. & 1794 & 4234 & n.i. & 14055 & n.i. & n.d \\
\hline & STD & n.i. & 3477 & 6685 & n.i. & 19626 & n.i. & n.d \\
\hline \multirow{2}{*}{$\sum 6 \mathrm{PCB}$} & $\mathrm{AM}$ & n.i. & 1673 & 3717 & n.i. & n.i. & 11226 & 41300 \\
\hline & STD & n.i. & 3335 & 7361 & n.i. & n.i. & 9427 & n.i. \\
\hline
\end{tabular}

\footnotetext{
${ }^{\text {a }}$ Wilcke et al. (1999a).

b Müller (1998).

c Ma et al. (2005).

d Motelay-Massei et al. (2004).

e Eusterbrock (1999).

${ }^{\mathrm{f}}$ Mandalakis et al. (2004).

g Covaci et al. (2001).

${ }^{\mathrm{h}}$ Institut für Hygiene und Umwelt (2001).

${ }^{\mathrm{i}}$ n.d. = no data.

${ }^{\mathrm{j}}$ n.i. $=$ no information.
} 
to be taken into consideration. Another important fact might be the short accumulation period because, as a typical third world country, Nepal was virtually free of industry and traffic before the 1970s.

\section{Conclusion}

Despite severe actual pollution, PAH and PCB contamination in urban soils of Kathmandu has not to be regarded as a problem. Average values are in range of reference background values. Intervention values are not reached by any of the compounds investigated. Pollutant concentrations are lower than in temperate regions but higher than in the tropics or subtropics. Most of the contamination can be explained by diffuse background sources, which are traffic and industrial emissions for PAHs and the ubiquity of POPs for both compound classes. The gutter is an exception as it acts like a trap, resulting in relatively high pollutant concentrations as a result of accumulation. Samples industry 1 and street 9 can be regarded as "hot spots". PAH ratios indicate that combustion of fossil fuels is the main source for PAHs in Kathmandu's soils. However, petrogenic sources also play a role. As the abundance of perylene in some samples is too high to be of pyrogenic origin, biological production must be the cause. The significantly more positive $\delta^{13} \mathrm{C}$ values for perylene in samples with elevated concentrations confirm this assumption. Tetra- and pentachlorobiphenyls are the most abundant PCBs. The congener pattern, the result of the cluster analysis and the low concentrations indicate that a background of ubiquitous PCBs is the main source of contamination. Pigments used in the textile and garment industry are a possible source of congener 35 .

Accelerated microbial degradation and volatilization, enhanced photodegradation before and after deposition, the relatively short accumulation time of pollutants and, in the case of the PCBs, the lack of acute contamination sources, might be reasons for the low concentrations. Concerning the state of soil pollution, Kathmandu fits rather well into a global distribution pattern. There exist numerous publications dealing with PAHs and PCBs in temperate regions. Compared with this, there is still a lack of studies concerning soil pollution in tropical and subtropical environments. Data on PCB levels are especially scarce. Therefore, to confirm the distribution pattern described above, more research is necessary.

\section{Acknowledgements}

We especially thank Dr. Krishna Karki for helpful guidance during the sampling period in Kathmandu. Further, we thank Dr. Gunter Ilgen at the Bayreuth Center for Environmental and Ecological Research (BayCEER), Bayreuth for providing access to the Accelerated Solvent Extractor, and Ilse Thaufelder, Martina Heider, Tanja Gonter and Tatiana Kramarewa for help in the laboratory. The research was partly funded by the German Research Foundation (DFG). We are also grateful to two anonymous reviewers for constructive comments.

\section{Associate Editor-D. Hunkeler}

\section{References}

Abraham, W.-R., Nogales, B., Golyshin, P., Pieper, D., Kenneth, N., Timmis, K., 2002. Polychlorinated biphenyl-degrading microbial communities in soils and sediments. Current Opinion in Microbiology 5, 246-253.

Atanassova, I., Brümmer, G., 2004. Polycyclic aromatic hydrocarbons of anthropogenic and biopedogenic origin in a colluviated hydromorphic soil of Western Europe. Geoderma 120, 27-34.

Ballschmiter, K., Zell, M., 1980. Analysis of polychlorinated biphenyls (PCB) by glass capillary gas chromatography. Fresenius Journal of Analytical Chemistry 302, 20-31.

Bamforth, S., Singleton, I., 2005. Bioremediation of polycyclic aromatic hydrocarbons: current knowledge and future directions. Journal of Chemical Technology and Biotechnology 80, 723-736.

Bliefert, C., 1997. Umweltchemie, second ed. Wiley-VCH.

Breivik, K., Sweetman, A., Pacyna, J., Jones, K., 2002. Towards a global historical emission inventory for selected PCB congeners - a mass balance approach 1 . Global production and consumption. The Science of the Total Environment 290, 181-198.

Chen, L., Ran, Y., Xing, B., Mai, B., He, J., Wei, X., Fu, J., Sheng, G., 2005. Contents and sources of polycyclic aromatic hydrocarbons and organochlorine pesticides in vegetable soils of Guangzhou, China. Chemosphere 60, 879-890.

Covaci, A., Hura, C., Schepens, P., 2001. Selected persistent organochlorine pollutants in Romania. The Science of the Total Environment 280, 143-152.

Dalla Valle, M., Jurado, E., Dachs, J., Sweetman, A., Jones, K., 2005. The maximum reservoir capacity of soils for persistent organic pollutants: implications for global cycling. Environmental Pollution 134, 153-164.

Eckrich, W., 1996. PCB. Industriechemikalie und Umweltschadstoff. www.uhst.de/pdf/PCB.pdf (06.07.05).

Eisenbrandt, G., Metzler, M., 1994. Toxikologie für Chemiker, Stoffe, Mechanismen, Prüfverfahren. Georg Thieme Verlag, Stuttgart.

Erickson, M., 2001. PCB properties, uses, occurence and regulatory history. In: Robertson, L.W., Hansen, L.G. (Eds.), 
PCBs - Recent Advances in Environmental Toxicology and Health Effects. University of Kentucky Press, Lexington, KY, USA.

Eusterbrock, L., 1999. Polyzyklische aromatische Kohlenwasserstoffe (PAK) und polychlorierte Biphenyle (PCB) in urbanen Böden Bayreuths. Bd. 66 of Bayreuther Bodenkundliche Berichte. Bayreuther Forum Ökologie.

FAO, 1998. World Reference Base for Soil Resources, Bd. 84. World Soil Resources Reports.

Frame, G.M., Cochran, J.W., Boewadt, S., 1996. Complete PCBcongener distribution for 17 aroclor mixtures determined by 3 HRGC systems optimized for comprehensive, quantitatives congener specific analysis. Journal of High Resolution Chromatography 19, 657-668.

Gautam, P., Blaha, U., Appel, E., Neupane, G., 2004. Environmental magnetic approach towards the quantification of pollution in Kathmandu urban area, Nepal. Physics and Chemistry of the Earth 29, 973-984.

Glaser, B., Amelung, W., 2002. Determination of ${ }^{13} \mathrm{C}$ natural abundance of amino acid enantiomers in soil: methodological considerations and first results. Rapid Communications in Mass Spectrometry 16, 891-898.

Gouin, T., Mackay, D., Jones, K.C., Harner, T., Meijer, S., 2004. Evidence for the grasshopper-effect and fractionation during long-range atmospheric transport of organic contaminants. Environmental Pollution 128, 139-148.

HMNG-MFD, 2005. www.mfd.gov.np/table.php (07.08.2005). His Majesty's Government of Nepal, Metereological Forecasting Division.

HMNG-MoPE, 2000. State of the environment, Nepal. His Majesty's Government of Nepal, Ministry of Population and Environment.

HMNG-MoPE, 2003. Nepal Population Report 2060. His Majesty's Government of Nepal, Ministry of Population and Environment.

Hwang, H.-M., Wade, T., Sericano, J., 2003. Concentrations and source characterization of polycyclic aromatic hydrocarbons in pine needles from Korea, Mexico, and United States. Atmospheric Environment 37, 22592267.

Institut für Hygiene und Umwelt, 2001. Coplanare PCB in Hamburger Oberböden, Bd. 60. Hamburger Umweltbericht.

Iwata, H., Tanabe, S., Sakai, N., Nishimura, A., Tatsukawa, R., 1994. Geographical distribution of persistent organochlorines in air, water and sediments from Asia and Oceania, and their implications for global redistribution from lower latitudes. Environmental Pollution 85, $15-33$.

Jiang, C., Alexander, R., Kagi, R., Murray, A., 2000. Origin of perylene in ancient sediments and its geological significance. Organic Geochemistry 31, 1545-1559.

Khalili, N., Scheff, P., Holsen, T., 1995. PAH source fingerprints for coke ovens, diesel and gasoline engines, highway tunnels, and wood combustion emissions. Atmospheric Environment 29, 533-542.

Krauss, M., Wilcke, W., Martius, C., Bandeira, A., Garcia, M., Amelung, W., 2005. Atmospheric versus biological sources of polycyclic aromatic hydrocarbons (PAHs) in a tropical rain forest environment. Environmental Pollution 135, 143-154.

Litten, S., Fowler, B., Luszniak, D., 2002. Identification of a novel PCB source through analysis of 209 PCB congeners by
US EPA modified method 1668. Chemosphere 46, 14571459.

Ma, L., Chu, S., Wang, X., Cheng, H., Liu, X., Xu, X., 2005. Polycyclic aromatic hydrocarbons in the surface soils from outskirts of Beijing, China. Chemosphere 58, 1355-1363.

Mackay, D., Shiu, W., Ma, K., 1991. Multimedia Environmental Models, Second ed. The Fugacity Approach. Lewis Publishers, Boca Raton, FL, USA.

Mandalakis, M., Gustafsson, O., Reddy, C.M., Xu, L., 2004. Radiocarbon apportionment of fossil versus biofuel combustion sources of polycyclic aromatic hydrocarbons in the Stockholm metropolitan area. Environmental Science and Technology 38, 5344-5349.

Mantis, J., Chaloulakou, A., Samara, C., 2005. PM10-bound polycyclic aromatic hydrocarbons (PAHs) in the Greater Area of Athens, Greece. Chemosphere 59, 593-604.

Mariotti, A., Balesdent, J., 1990. ${ }^{13} \mathrm{C}$ natural abundance as a tracer of soil organic matter turnover and paleoenvironment dynamics. Chemical Geology 84, 217-219.

Marschner, B., 1998. Sorption von polyzyklischen aromatischen Kohlenwasserstoffen (PAK) und polychlorierten Biphenylen (PCB) im Boden. Journal of Soil Science and Plant Nutrition $162,1-14$

McRae, C., Suna, C.-G., Snape, C., Fallick, A., Taylor, D., 1999. ${ }^{13} \mathrm{C}$ values of coal-derived PAHs from different processes and their application to source apportionment. Organic Geochemistry 30, 881-889.

Motelay-Massei, A., Ollivon, D., Garban, B., Teil, M., Blanchard, M., Chevreuil, M., 2004. Distribution and spatial trends of PAHs and PCBs in soils in the Seine River basin, France. Chemosphere 55, 555-565.

Müller, U., 1981. Thimi. Social and economic studies on a Newar settlement in the Kathmandu valley. Bd. 49 of Giessener Geographische Schriften. Selbstverlag des Geographischen Instituts der Justus-Liebig-Universität Giessen.

Müller, S., 1998. Polyzyklische aromatische kohlenwasserstoffe (PAK) und polychlorierte biphenyle (PCB) in korngrößenund dichtefraktionen urbaner Böden Bangkoks. Diplomarbeit, Universität Bayreuth.

Okuda, T., Kumata, H., Naraoka, H., Takada, H., 2002a. Origin of atmospheric polycyclic aromatic hydrocarbons (PAHs) in Chinese cities solved by compound-specific stable carbon isotopic analyses. Organic Geochemistry 33, 1737-1745.

Okuda, T., Kumata, H., Zakaria, Z., Naraoka, H., Ishiwatari, R., Takada, H., 2002b. Source identification of Malaysian atmospheric polycyclic aromatic hydrocarbons nearby forest fires using molecular and isotopic compositions. Atmospheric Environment 36, 611-618.

O'Malley, V.P., Burke, R.A., Schlotzhauer, W., 1997. Using GCMS/Combustion/IRMS to determine the ${ }^{13} \mathrm{C} /{ }^{12} \mathrm{C}$ ratios of individual hydrocarbons produced from the combustion of biomass materials - applications to biomass burning. Organic Geochemistry 27, 567-581.

Omar, N., Radzi Bin Abas, M., Ketuly, K., Tahir, N., 2002. Concentrations of PAHs in atmospheric particles (PM-10) and roadside soil particles collected in Kuala Lumpur, Malaysia. Atmospheric Environment 36, 247-254.

Pokhrel, D., Viraraghavan, T., 2005. Municipal solid waste management in Nepal: practices and challenges. Waste Management 25, 555-562.

Sapkota, B., Dhaubhadel, R., 2002. Atmospheric turbidity over Kathmandu Valley. Atmospheric Environment 36, 1249-1257. 
Schmitt, J., Glaser, B., Zech, W., 2003. Amount-dependent isotopic fractionation during compound-specific isotope analysis. Rapid Communications in Mass Spectrometry 17, 970977.

Sharma, C., 1997. Urban air quality of Kathmandu valley. Atmospheric Environment 31, 2877-2883.

Shrestha, R., Malla, S., 1996. Air pollution from energy use in a developing country city: the case of Kathmandu Valley, Nepal. Energy 21, 785-794.

Sun, C., Cooper, M., Snape, C.E., 2003. Use of compoundspecific $\delta^{13} \mathrm{C}$ and $\delta \mathrm{D}$ stable isotope measurements as an aid in the source apportionment of polyaromatic hydrocarbons. Rapid Communications in Mass Spectrometry 17, 26112613.

Thiele, S., Brümmer, G., 2002. Bioformation of polycyclic aromatic hydrocarbons in soil under oxygen deficient conditions. Soil Biology and Biochemistry 34, 733-735.

Venkatesan, M., 1988. Occurrence and possible sources of perylene in marine sediments - a review. Marine Chemistry 25, 1-27.

Wania, F., Mackay, D., 1996. Tracking the distribution of persistent organic pollutants. Environmental Science and Technology 30, 390A-396A.

Wilcke, W., 2000. Polycyclic aromatic hydrocarbons (PAHs) in soil - a review. Journal of Soil Science and Plant Nutrition 163, 229-248.
Wilcke, W., Amelung, W., Krauss, M., Martius, C., Bandeira, A., Garcia, M., 2003a. Polycyclic aromatic hydrocarbon (PAH) patterns in climatically different ecological zones of Brazil. Organic Geochemistry 34, 1405-1417.

Wilcke, W., Krauss, M., Amelung, W., 2002. Carbon isotope signature of polycyclic aromatic hydrocarbons (PAHs): evidence for different sources in tropical and temperate environments? Environmental Science and Technology 36, 35303535 .

Wilcke, W., Krauss, M., Baranciikova, G., 2003b. Persistent organic pollutant concentrations in air- and freeze-dried compared to field-fresh extracted soil samples of an eastern Slovak deposition gradient. Journal of Soil Science and Plant Nutrition 166, 93-101.

Wilcke, W., Lilienfein, J., Lima, S., Zech, W., 1999a. Contamination of highly weathered urban soils in Uberlândia, Brazil. Journal of Soil Science and Plant Nutrition 162, 539-548.

Wilcke, W., Müller, S., Kanchanakool, N., Niamskul, C., Zech, W., 1999b. Polycyclic aromatic hydrocarbons in hydromorphic soils of the tropical metropolis Bangkok. Geoderma 91, 297-309.

Zakaria, M.P., Takada, H., Tsutsumi, S., Ohno, K., Yamada, J., Kouno, E., Kumata, H., 2002. Distribution of polycyclic aromatic hydrocarbons (PAHs) in rivers and estuaries in Malaysia: a widespread input of petrogenic PAHs. Environmental Science and Technology 36, 1907-1918. 